This item was submitted to Loughborough's Research Repository by the author.

Items in Figshare are protected by copyright, with all rights reserved, unless otherwise indicated.

\title{
Fashion statements: communication and culture
}

PLEASE CITE THE PUBLISHED VERSION

PUBLISHER

Palgrave Macmillan () Ron Scapp and Brian Seitz

VERSION

SMUR (Submitted Manuscript Under Review)

LICENCE

CC BY-NC-ND 4.0

REPOSITORY RECORD

Barnard, Malcolm. 2019. "Fashion Statements: Communication and Culture". figshare. https://hdl.handle.net/2134/15122. 
This item was submitted to Loughborough's Institutional Repository (https://dspace.lboro.ac.uk/) by the author and is made available under the following Creative Commons Licence conditions.

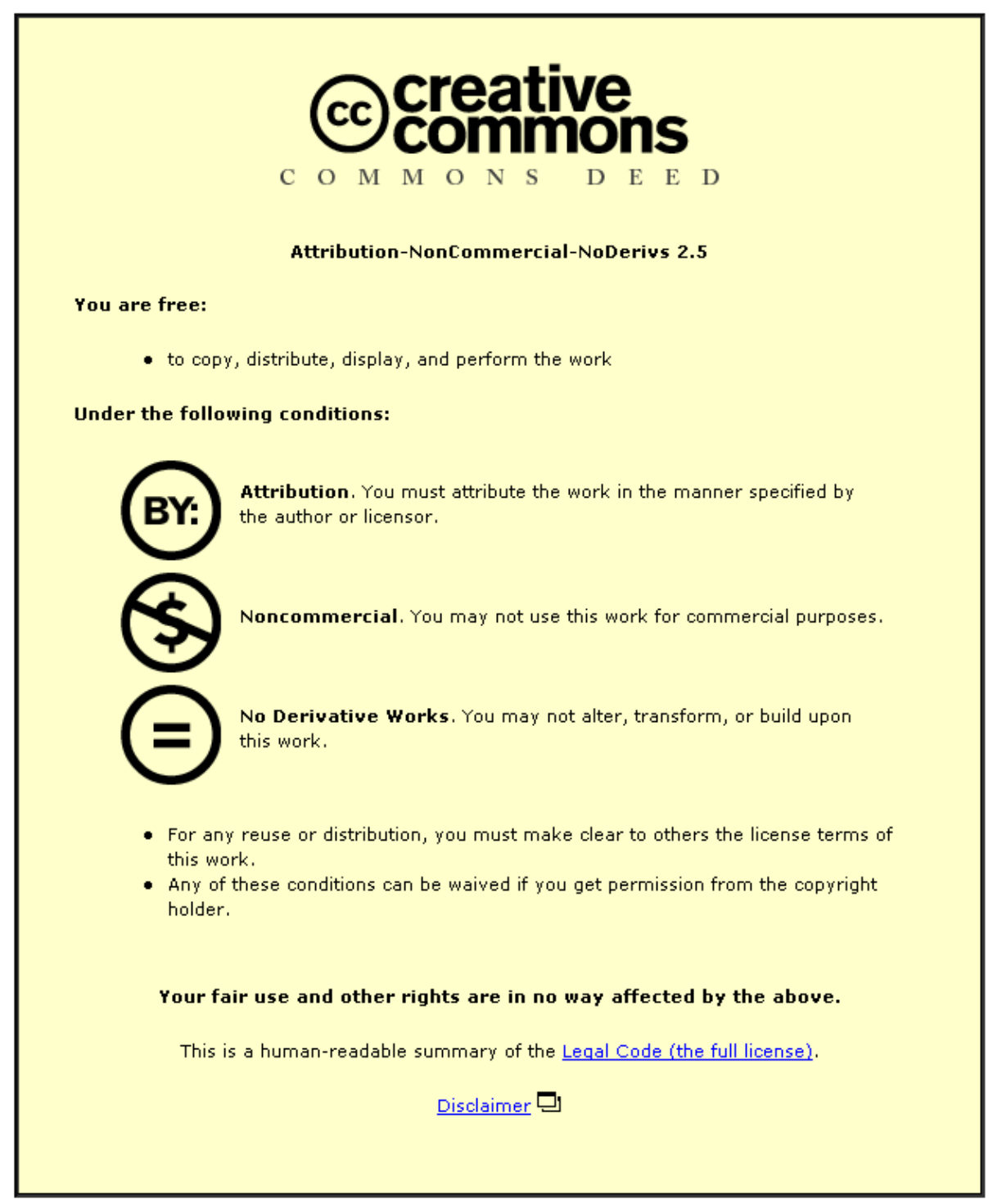

For the full text of this licence, please go to: http://creativecommons.org/licenses/by-nc-nd/2.5/ 
Malcolm Barnard

Loughborough University, U.K.

\section{Fashion Statements: Communication and Culture}

\section{Introduction}

Modern, western people are accustomed to the way in which the clothes they wear begin their lives as 'trendy' or 'stylish', but then start to age, become 'stale' and are no longer trendy or stylish. We are used to the idea that clothes come, or go, in and out of fashion and the English phrase 'old hat' would appear to describe a wellunderstood drift from literal to metaphorical usage. Thus, fashion, the idea that what people wear may or may not be the current or latest style, is clearly understood in modern and western cultures. Also, modern, western people are familiar with the idea that the clothes they and others wear are meaningful. Clothes are selected for purchase, and for wearing, according to the meaning we believe them to have, or the messages we believe them to send. A novelty tie or a strappy frock worn to a job interview in the city, for example, 'sends out all the wrong messages'. The English phrase again appears to give away an entire culture's implicit understanding of fashion's communicative function. Both fashion itself and the communicative function of fashion are perceived as being unproblematic and well-understood in modern western cultures, as evidenced by the title of the current volume.

However, while the conception of fashion as a temporal sequence of 'looks' or styles that is taken for granted by certain cultures may be relatively uncontroversial, the conceptions of meaning and communication that are presupposed in the notion that fashion or clothing are meaningful or communicative phenomena certainly are not. For example, presupposed in the apparently unproblematic and well-understood accounts of the sort of meaning that items of fashion and clothing possess is the idea that meaning is a message. Meaning here is conceived as the 'sending out', or expression, of a 'message', which is itself conceived as some form of inner mental content or statement. Similarly, presupposed in the above accounts of the sort of communication that fashion performs is the idea that communication is the conveying or transmission of that message from one place to another. This paper will try to define and explain the nature of fashion statements; it will investigate the presuppositions of the conceptions of meaning and communication noted above, outline what is problematic about them and attempt to suggest a more accurate and productive way of thinking about them.

In order to do these things, the rest of this essay will be divided into four sections. The first section will outline a brief definition and explanation of fashion. In this section, fashion and clothing will be defined and explained as meaningful and cultural phenomena. The second section will consider the notion of meaning that is presupposed by many accounts of fashion and clothing. In this section, meaning will be established as a profoundly cultural phenomenon. The third section will explain the notion of communication. It will argue that communication is not the sending/receiving of messages, but that it is the cultural construction of meaning and thereby identity. The fourth section will take two examples of fashion and clothing and show how they may be explained in terms of meaning and communication. 


\section{Fashion}

I am not proposing a particularly sophisticated, overly technical or calculatedly controversial definition of fashion in this section. However, even to follow Anne Hollander's deceptively simple definition of fashion as what modern 'western' people wear (1), is already to offer an all-inclusive definition of fashion, which includes everything that people wear, not just that which is 'up to the minute'. It is also to court challenges as to what is to count as 'western' and as 'modern'. So, the definition of fashion offered here includes, (but is not exhausted by), all instances of what people wear, from catwalk creations, through High Street and Outlet purchases, to police and military uniforms. And it insists on both the modernity and 'westernity' of fashion. Indeed, the existence of fashion in a society may be a good test of whether that society is either modern or western: a society in which there are not different classes, no social structure, and in which upwards mobility in a class structure is neither possible nor desirable has no need of fashion and might reasonably be said to be neither modern nor western.

While fashion may be about bodies, as Joanne Entwistle says (2), it is also, as Entwistle also says, about 'fashioned' bodies. And by 'fashioned' bodies, I understand produced, cultured bodies, because one of the meanings of fashion (as a verb) is 'to make' or 'to produce'. The fashioned body is therefore a made or produced body. To that extent, there can be no such thing as 'the body': the body is always already a constructed and meaningful body; it is a cultured or cultural body, because differently cultured bodies wear different fashions. Another way of saying this is to say that fashion is meaningful, (as was said above), and that it is therefore about communication. This is because saying that fashion is meaningful is to say that fashion is a cultural phenomenon. The reason for this, in turn, is that culture is about shared meanings and the communication and understanding of those meanings. Given this, and in the light of what Entwistle says about the fashioned body, we can say that differently cultured bodies communicate different things, (meanings), by means of the different things (clothes, fashion) that they wear.

Fashion has been established as being meaningful and as communicative. It has also been established as a profoundly cultural entity. Therefore, the next problem for this paper is explaining (a) what sort of meaning fashion communicates and (b) what sort of communication fashion is. Now, I also want to argue that fashion is one of the ways in which people are constructed as members (and/or non-members) of cultural groups. The reference to culture was a significant part of the definition or explanation of what fashion is and that definition inevitably refers to culture. So the third problem for this essay is (c) how fashion as meaningful communication constructs people as members, or non-members, of cultural groups

By way of light-hearted relief, the Roz Chast cartoon "The Girl With the Sensible Shoes" gives some idea of the sort of meanings that fashion does not communicate and illustrates one of the ways in which it does not communicate those meanings. Fashion statements are not like spoken statements, or the speech bubbles in cartoons, and they are not about such things as not forgetting to send your Aunt Hilda a thankyou note. Similarly, meanings are not 'messages' in any simple sense and fashion does not communicate messages in terms of a 'speaker/listener', or 'sender/receiver' model. These ideas will be discussed in more detail below. 


\section{Meaning}

What this section requires is a definition of meaning that will be of use in the explanation of fashion and communication. It also needs an account of meaning and communication that will perform the tasks demanded in the explanation and analysis of what has become known as visual culture. It must be said that the account of meaning to be proposed here cannot even pretend to be entirely uncontroversial. There are many people who would argue that it is not entirely convincing. However, I am trying to avoid an account of meaning where meaning is a function of either individual intention, (what is going on in someone's head) or of the item of clothing itself. In the first case meaning is something that is expressed and conveyed and in the second it is something like a natural or inherent property of the item of clothing itself (like colour or texture) and neither can be supported. Basically, I have in mind Roland Barthes' version of connotation, but without the sense that somewhere beneath connotation there is denotation. For Barthes, it will be recalled, denotation is the 'literal' or 'dictionary' definition of a word and connotation is the set of associations that accrue to it. Denotation can be correct or incorrect, precisely because it is thought of as being 'literal' or 'natural' in some way. Because it is 'cultural' and dependent on an individual's socio-historical location, connotation does not admit of being correct or incorrect. This essay will try to make a case for meaning being like connotation because and insofar as Barthes' version of connotation already refers to the work of culture. That is, meaning here is connotation 'all the way down' and not 'built' or 'based' on anything that is not connotation. This conception of meaning will be used because it already and explicitly depends upon culture: Barthes' connotational meaning is explicitly the product of culture. Meaning on this account is a product of cultural beliefs and values, and different beliefs and values generate different meanings.

In his famous account of the 'Panzani' advertisement in "Rhetoric of the Image" (3) Barthes identifies five connotational meanings, or 'connotative signs' and he scrupulously explains each one in terms of the culturally specific knowledges (structures of ideas) needed to understand, or construct, those meanings. One, for example, is 'Italianicity' and he says that, in order to be able to understand, or construct that meaning, one needs to be familiar with certain tourist stereotypes: members of a culture which has no tourist industry, or no stereotype of Italians, will not be able to understand that meaning. He also points out that Italians will also have a different take on the ad from non-Italians, precisely because they are Italian: membership or non-membership of the cultural group is here explicitly linked with the production of different meanings. On this account, then, meaning is a product of the interaction between the beliefs and values an individual holds as a member of a particular culture and some example of visual culture. In Barthes' case, the example of visual culture is the 'Panzani' ad and in our case it is fashion.

Such an account of meaning is not inconsistent with other (cultural studies-type) accounts of meaning in that meaning does not pre-exist the interaction between an individual member of a culture's beliefs and values and the example of visual culture. Meaning is sometimes said to be a product either of the item in question or of individual intention: a tweedy jacket may be said to signify 'rustic simplicity', for 
example, or an individual may say they are wearing a shirt because it means something unique to them. But on this account, a piece of fashion or clothing is not meaningful in itself and a piece of fashion or clothing is not meaningful because of any individual intention.

Of course, one may say that one is aware of, or indeed knows, the meaning an item of clothing has. But this formulation is surely a species of shorthand for saying that one knows the meaning an item of clothing has for, or within, a culture; it is therefore already to have interacted with that culture's values and beliefs. So, shared meaning constructs one as member of cultural group. If one does not share the meaning, then one is not constructed as a member of that social group. If you do not share or understand the meaning, then you are not produced or reproduced as a member of the culture.

\section{Communication}

The model of communication that is adopted in this essay is essentially a semiological/cultural studies type one according to which communication is a negotiation of meaning through the interaction between items of visual culture and the values (beliefs and ideas) held by an individual as a member of a cultural group. It is also one with which those who believe that communication is expression, or reflection or the sending and receiving of a message are likely to disagree.

Fashion communication as expression is the idea that something going on inside someone's head, individual intention, is somehow externalised and made present in a garment or an ensemble. It may also be the idea that entire cultures can express themselves in or through what members wear. Joanne Entwistle, for example, says that clothes 'can be expressive of identity' (4). She also says that clothing is 'part of the expressive culture of a community' (5). Both individuals and cultural communities can use fashion to express or make externally visible what were 'internal' and invisible ideas and beliefs.

Fashion communication as reflection is the idea that what people wear is a reflection or mirroring of something else. That something else may be a society's social or economic structure, or it may be a culture's values, for example. On this model of communication, people may claim that Victorian women wear tight corsetry, voluminous bustles and tight-shouldered dresses because they are reflecting their culture's idea of women as weak and helpless. Other people may claim that upperclass Victorian women wear expensive dresses and their lower-class servants wear cheap dresses because they are reflecting their society's economic structure. However, the communication of gender in fashion is not the reflection of something else. It is not, for example, the reflection of a culture's values, for example. The Victorian women are not reflecting their culture's view of them as weak, dependent and immobile: they are weak, dependent and immobile. Similarly, upper-class Victorian women are not reflecting the economic structure: dress is one of the ways in which economic structure is produced and reproduced.

On the sender/receiver model of communication, messages are encoded by a sender and sent, or transmitted through a channel to a decoder or receiver. Following this 
theory's origins in telecommunications engineering, the paradigm case is that of telephony: the sender (encoder) is the speaking individual, the channel is the telephonic equipment and the receiver is the listener (decoder) on the end of the line. Should the message arrive at the receiver in a form other than that in which it was transmitted, communication theorists will speak of a communication problem or breakdown and appeal to concepts such as 'noise' to explain the unexpected form. Insofar as most analysts seem to agree that fashion is not a language in any straightforward sense, they may be taken to agree that a simple version of the sender/receiver model cannot explain fashion. But it is not difficult to find people who are happy to assert that fashion and clothing are used to convey or 'send messages'. Elizabeth Rouse, for example, uses this notion in her Understanding Fashion when she writes of fashion 'conveying' an impression (6). And Eicher, Evenson and Lutz (2000) suggest that 'individuals often select items of dress because of the personal or public meaning that it conveys' (7).

There is another Roz Chast cartoon which explicitly mocks this conception of fashion communication, claiming to have 'decoded' the 'fashion statements of Rhonda Perlmutter III'. Fred Davis is more cautious and, while committed to the idea that fashion is some sort of communication, is wary of the idea that it is exactly like spoken or written language. Rather, he prefers to think of it in less 'precise' terms, in terms of 'aesthetics' or as being more like art or music (8). Such circumspection is to be distinguished from the approach of someone like Alison Lurie in The Language of Clothes, where she becomes so embroiled in a metaphor of clothing as a language that she takes the metaphor literally, (if that is possible).

I want to argue that if meaning is a cultural construction, in the manner of connotation, then it is not the sort of thing that can be reflected, expressed, sent, received, conveyed, or transmitted, and communication cannot involve any of these things. So, I want to argue that communication through fashion is not reflection, nor is it either individual or cultural expression. The points made above also suggest that we need to be a little careful with this notion of expression. This is because the notion of communication as expression involves the idea of simply moving something from 'inside' someone's head, or a cultural community's 'unconscious' (a meaning, intention or value) to 'outside'. Expression, that is, is a metaphor: it is a metaphor of conveying or transmitting something from one place to another. The problem here, of course, is that metaphor is itself a metaphor, and one that is dependent on the notion of 'conveying' for any rhetorical power it possesses. The 'meta' in 'metaphor' means 'beyond' or 'over' and the 'phor' means 'to carry'. Communication as a conveying employs a transport metaphor, but metaphor is itself already a figurative use of the notion of transport; it is itself a transport metaphor. As a result, this essay suggests that there are problems involved in believing that meaning is expression and that communication is a transmitting or conveying of a meaning.

The notion of meaning that is being followed in this essay suggests that meaning is constructed in the interaction between an individual's values and beliefs (which they hold as a member of a culture) and the item of visual culture. If meaning works in this way, as an interaction, then it cannot simply be transported or conveyed in communication. Consequently, as the idea of expression uses a metaphor of transportation, neither cultures nor individuals can be said in any simple way to be 
'expressing' themselves through what is worn; it is more accurate to say that identity is being constructed and reproduced.

Finally, it is worth noting that there is one problem that is equally relevant to all the conceptions of communication discussed so far. It is that, according to the model of communication as conveying, something has to pre-exist the conveying or sending. As a passenger on a bus or train, for example, pre-exists their being conveyed by that train or bus, so meaning on this model pre-exists communication. Colin Campbell rightly and mercilessly takes issue with this model of communication in his essay "When The Meaning Is Not A Message: A Critique Of The Consumption As Communication Thesis" (9). He is correct to critique the model of communication, but the notion of communication in or through fashion need not suppose that communication is the sending and receiving of a message. This paper is committed to arguing that communication through fashion is not a simple sending and receiving of messages. This is because meaning does not pre-exist the process of communication, the negotiation between an individual's beliefs and ides and the example of visual culture. And because meaning does not pre-exist the members of cultures who are communicating, communication cannot be the sending or receiving of a pre-existing message. There is no meaning until the interaction between cultural values and items of fashion. This is why the argument is made here that fashion is not a vehicle for conveying messages.

Indeed, in order for any of these phenomena (expression, conveying or reflection), to happen, it seems reasonable to suppose that there is some thing that exists prior to the expression, conveying or reflection of that thing. This is the origin of a major, if usually unacknowledged, difference between fashion theorists on these matters. There are those who believe either that something can meaningfully exist prior to representation or that something exists beyond representation and there are those who believe that there can be no such priority or beyond. For the former, such things as 'the body', or 'individual intention' play the role of that which exists outside of, or prior to, representation. Taking this position, it is perfectly possible to say that something, (a meaning), pre-exists the reflection, conveying or expression of that meaning. For the latter, such things as the body and individual intention literally make no sense unless they are represented. According to this latter position, it is impossible for meaning to pre-exist the process of communication. For what it is worth, I don't think that there is a 'beyond' to representation. I am with Derrida here: when he says that there is nothing outside the text (10), I take him to mean that, in order for anything to be meaningful, it must necessarily be represented. Similarly, I do not think that anything can pre-exist expression, or representation, even in experience or spoken/thought language. This is a question raised, and some would say answered, by Wittgenstein, when he argues in his Philosophical Investigations (11) that there are and can be no private languages. Communication, then, is either not-private (that is, it is shareable) or it is not communication.

Rather, on the account presented in this paper, communication is the negotiation of meaning: it is the result or product of the interaction between cultural values (ideas and beliefs) and the visual. Communication is also the process in which an individual is, or is not, constructed as a member of a cultural group. If I may argue by analogy in order to illustrate what I mean here: when I watch 'Sex and the City' or the football 
on tv, the values and beliefs I hold as a result of my social and cultural positions as a white, middle-class European male generate the meanings of the programmes for me. Meaning is a product of the interaction between culture - cultural values, beliefs and ideas - and the visual. The meanings that I construct are shared with other white, middle-class European males. We are likely to agree in our interpretation of the show, or the inestimable value of football on tv, for example. It is the sharing of the values (and thus the meanings) that makes us into an identifiable cultural group; it is this sharing, that is, that makes us into an 'us'.

Members of other cultural groups will construct the meanings differently. NonEuropean, or Muslim, or old, or working class women, for example, will almost certainly construct entirely different meanings for 'Sex and the City'. And this is because they will hold different beliefs and values. Those shared meanings are what construct and identify people as members of that group. Therefore, the meaning of items of fashion will likewise be produced through the interaction between cultural values and ideas and the visual appearance of the items of fashion.

\section{Case Studies}

The first case study concerns what President Bush and Prime Minister Blair are wearing in a press photograph of the meeting of the Euro-Atlantic Partnership Council in June 2004 and the second concerns 'hoodies', short hooded jackets that have recently acquired demonic status in some parts of the British news media.

In this photograph, Bush and Blair are wearing dark suits, light shirts and red ties. Notwithstanding the fact that this picture has been chosen to support an argument, the case against either man being engaged in any form of individualistic self-expression would appear already to be made. What is being claimed here is that neither man is sending a message, or using what they are wearing to convey a message. Both men know perfectly well some of the more dominant meanings that will be constructed by those viewing them and the photograph and they put together an outfit or a 'look' accordingly. In the terms of the sender/receiver model, this is effectively to suggest that the receiver is determining the message to some extent; it is an odd message that is constructed by the receiver, but that is what the proponents of the sender/receiver model of communication are effectively suggesting. Both Bush and Blair already know that a dark suit, light shirt and contrasting tie mean 'middle class', 'serious', 'authoritative', 'businesslike' and, for that matter, 'masculine' to the people they will be dealing with at the meeting and that is why they have put together such similar outfits.

This is not to say that both men know all the meanings of their suits and ties that might be constructed by all cultural groups; they do not necessarily know all of the possible structures of beliefs and values that suits and ties may be interpreted in terms of. For example, given their particular situations in 2004, it is unlikely that either man would wish to offend Christians or Muslims but some Islamic purists consider it haram, or prohibited, to wear ties made entirely of silk (13) and the frog, (as featured on what is reportedly Blair's favourite tie), has long been a Christian symbol of uncleanliness. In this example, then, 'alternative' or 'new' interpretations of items of clothing may be explained as being constructed by people who either (a) know how the structure of cultural beliefs and values extends beyond the limits understood by the wearer or (b) are able to construct other parts of that structure. 
Someone else who is neither expressing his individuality nor sending a message in the sense assumed by the sender/receiver model is Osama bin Laden. He regularly appears in photographs wearing a combat jacket over white robes with white headgear. He knows very well that fellow Wahhabi Muslims will know that the white robes and headgear mean purity and he knows just as well that western audiences will know that the combat jacket and AK47 mean a certain level and form of military/technological threat and also a specific form of masculine identity (13). His outfit is constructed already knowing the different meanings that will in turn be constructed for it by different cultural groups and this, clearly, is not to convey a message in any simple sense.

The second case study is that of the 'hoodie'. A 'hoodie' is a short hooded jacket, with or without a zipper on the front. Recently in the U.K., 'hoodie' has also become the name given to those wearing such a jacket and it refers specifically to young people who are perceived by respectable, law-abiding middle-class observers and journalists as lower-class, drug-taking shop-lifters. The meaning communicated by these garments is now so powerful in the U.K. that hoodie wearers are being denied access to shopping malls because they are perceived as a shop-lifting threat. This constitutes a different kind of example in that here the structures of ideas and beliefs within which members of cultures construct meaning are being 'extended': new and different meanings are being made possible by 'continuing' or extending existing patterns of beliefs in order to make new meanings. This may be seen by considering previously existing structures within which hooded garments have been constructed in the past.

Hooded garments have a long history and there is nothing about hooded garments that is inherently or naturally lower-class, or that inevitably indicates that the wearer is a delinquent and a threat to society. Academics, for example, have long worn hooded garments to communicate their status within the University. Certain religious orders are also in the habit of wearing hooded garments. And the humour in Neil Bennett's cartoon in which a hoodied-up Christopher Robin suggests to Pooh and Tigger that they go and 'hang about on the footbridge' is generated by the realisation that when Christopher Robin, the golden-haired goody-goody of A. A. Milne's poem "Vespers", pulls his hood right over his head so that nobody knows he's there at all, nobody even thinks of him doing it to conceal his identity whilst engaged in a bit of casual vandalism. In these cases, among the meanings constructed by and for certain cultural groups are 'learned', 'pious' and 'innocent childhood'.

What is happening in the demonisation of hoodie-wearers is that the (British) print and television media are providing a new application of a set of values and ideas in terms of which certain cultural groups may construct the meaning of a particular garment. Those beliefs and ideas (shop-lifting, young people as threat, for example) are already present in the culture, but they have never been associated with this particular garment. Consequently, the structure of beliefs and ideas is being extended to include this new garment and thus to construct new meanings. And when a particular cultural group (middle-class, middle-aged affluent consumers, for example) interprets hoodies as the latest evidence of moral decay, it is the result of the 
interaction between the values and ideas they hold and the garment they are looking at. Again, meaning here is not simply a message being sent to a receiver.

\section{Conclusion}

This essay has attempted to define and explain the nature of fashion statements. In order to do this, it has had to investigate meaning and communication and explain what sort of meaning it might be that fashion has and what sort of communication it can be that fashion accomplishes. Meaning and communication have been explained in terms of culture: neither makes any sense without reference to culture. Culture has been understood as structures of beliefs, ideas and values and as the communication of those beliefs, ideas and values in the construction (or not) of individuals as members (or not) of cultural groups. The construction of meaning by individuals, then, is one of the ways in which those individuals are themselves constructed as individuals. It is also one of the ways in which different, new or alternative meanings are constructed. Fashion statements, then, are one of the ways in which cultural structures and individual agency relate and in which they are both constructed and reproduced.

\section{Endnotes}

1. Hollander, Anne, Sex and Suits (New York: Alfred A Knopf, 1994) p.11

2. Entwistle, Joanne, The Fashioned Body (London: Polity, 2000) p.1

3. Barthes, Roland, "Rhetoric of the Image", in Image-Music-Text (Glasgow, Fontana) p.

4. Entwistle, Joanne, The Fashioned Body (London, Polity 2000), p. 112

5. Entwistle, Joanne, The Fashioned Body (London, Polity 2000), p. 66

6. Rouse, Elizabeth, Understanding Fashion (Oxford, Blackwell 1989), p. 24

7. Eicher, Joanne, B., Evenson, Sandra Lee, and Lutz, Hazel A., The Visible Self (New York Fairchild 2000), p. 297

8. Davis, Fred, Fashion, Clothing and Identity, (Chicago, University of Chicago Press, 1992), p. 11

9. Campbell, Colin, "When The Meaning Is Not A Message: A Critique Of The Consumption As Communication Thesis”, in Nava, Mica et al (eds) Buy This Book (London, Routledge, 1997)

10. Derrida, Jacques, Of Grammatology (Baltimore and London, Johns Hopkins University Press, 1974) p. 158

11. Wittgenstein, Ludwig, Philosophical Investigations (Oxford, Blackwell, 1953)

12. www.pakistanlink.com/religion/97/re05-23-97.html (accessed July 2005)

13. See Mansell, Philip, Dressed to Rule (New Haven, Yale University Press, 2005)

'Postscript' for more on this.

\section{Bibliography}

Barthes, Roland, "Rhetoric of the Image”, in Image-Music-Text, (Glasgow, Fontana/Collins, 1977) 
Butler, Judith, Gender Trouble: Feminism and the Subversion of Identity, (London, Routledge, 1990)

Campbell, Colin, "When The Meaning Is Not A Message: A Critique Of The Consumption As Communication Thesis", in Nava, Mica et al (eds) Buy This Book, (London, Routledge, 1997)

Davis, Fred Fashion, Clothing and Identity, (Chicago, University of Chicago Press, 1992)

Derrida, Jaques, Of Grammatology (Baltimore and London, Johns Hopkins University Press, 1974)

Eicher, Joanne B., Evenson, Sandra Lee and Lutz, Hazel A., The Visible Self, (New York, Fairchild, 2000)

Entwistle, Joanne, The Fashioned Body, (London, Polity, 2000)

Hollander, Anne, Sex and Suits, (New York, Kodansha International, 1994)

Lurie, Alison, The Language of Clothes, (London, Bloomsbury, 1992)

Mansell, Philip, Dressed to Rule, (New Haven, Yale University Press, 2005)

Nava, Mica, et al. (eds) Buy This Book, (London, Routledge, 1997)

O'Sullivan, Tim, et al Key Concepts in Communication and Cultural Studies, (Second Edition, London, Routledge, 1994)

Rouse, Elizabeth, Understanding Fashion, (Oxford, Blackwell, 1989)

Wittgenstein, Ludwig, Philosophical Investigations (Oxford, Blackwell, 1953) 